\title{
Library Service Satisfaction of library users in Cendrawasih University Library Unit
}

\author{
Thereseta Evilianingsih \\ Universitas Cenderawasih, Indonesia \\ there_evi@yahoo.com
}

\begin{abstract}
This study aims to identify and analyze how much influence the quality of library services to the satisfaction of the library users at the University Library of Cenderawasih. Research method used in this study is the method of observation, interviews, questionnaires, and literature study using a Likert scale and sampling method used is Probability Sampling with Proportional stratified random sampling, which means sampling of members of the population at random and stratified proportional so that samples obtained 90 samples. The analytical method used is multiple linear regression method. The results showed that the quality of service which consists of tangible, reliability, responsiveness, assurance, empathy, and together have a positive influence. Service quality has a significant effect on satisfaction library users at the University Library of Cenderawasih. The variables that have a significant influence on satisfaction library users are tangibles, reliability and empathy. Responsiveness and assurance does not have a significant influence on satisfaction in the Library Unit Uncen library users. The most dominant variable is empathy.
\end{abstract}

Keywords: Accountability services, quality service, reliability, responsiveness, assurance, empathy, and tangible, library users satisfaction

\section{Introduction}

Library as one unit of service providers experienced a significant impact as a result of globalization and business competition. Libraries are required to be sensitive to the response and the need library user. Therefore, the library has an interest in the provision of facilities and by utilizing advances in technology in order to provide added value for user. The ability of libraries in providing information that is useful and can be used by library user will determine the value and satisfaction library user to the library. Along with advances in information and communication technology, today's paradigm of a library began to change. Library is present not only as a place or warehouse just books but also as a resource center. Diverse knowledge and information presented complete, can be found and reprocessed into new knowledge. Moreover if the library is a library of Higher Education which is the heart of the College itself. As for the rate "heart" is very dependent on the support of parent institutions that shelter, the managers and the library user interacting there. Balanced interactions between the three components that make libraries become qualified. Automatically the value of a university can be measured by the quality of library services provided to the library user.

In Law No. 43/ 2007 on the Library, article 24 states that (1) every college held a library that meets national standards library with attention to National Education Standards which has a collection sufficient to support the implementation of education, research, and community service, (2) The college library develop library services based on information and communication technologies by allocating funds for library development. In order to ensure the sustainability of quality library services that it is necessary to have a system that can evaluate which is expected to provide an overview and input. Overview intended to library user knows the exact whereabouts of the library. Meanwhile, the input is meant to look and search for solutions to the problems faced by library user. In the end quality library services that are used to meet the expectations and needs of library user. Uncen library as one component of an academic at the University of Cendrawasih (Uncen) should be able to play a role in helping the academic process. Library Uncen a footstool in meeting the information needs of the academic community in Uncen environment. Every year the Library Uncen faced with the problems and complaints library user to the services provided library. And based on the suggestion box that recorded during the year 2012, the majority of library user wants more intensive service of the library, especially the comfort room, the availability of relevant textbooks, journals, personnel services, opening hours, availability of internet facilities and the location and level of security. Currently the use of the 
library by the academic community in the Library Uncen Uncen still low. By looking and based on the data in the Library Uncen, the level of lending by the academic community Uncen during January-June 2013 is still low, where the existing data in the Library Uncen shows the level of the average visit is also low and even declining.

From the data obtained it was clear that the number of collections each year no increase significantly it is because every year there is no provision or purchase of new books recently that in 2009 amounted to 24173 copies, the number of visitors 20998 people, the number of borrowers a maximum of 1,873 people and the number of books that are returned by $92.62 \%$, the number of books read greatest place 19:04\%. In 2011 and 2012 the number of collections remained unchanged at 27829 copies it is possible Libraries Uncen not propose or of the rector who did not support the proposal of the library, only the addition of books prize, while the number of visitors in 2011 the highest number of traffic levels by the academic community as many as 22682 people. And in 2013 there was the addition of the proposed procurement in 2012 with the title number as many as 334 titles and 2,596 copies, but it is unfortunate good number of visitors, the borrower, the loan book dropped dramatically, and only the returned books rose to $96.11 \%$.

\section{Literature Review}

Library Service Quality: Quality can be defined simply as "a measure of how good the level of service provided able to match the expectations of users" (Tjiptono, 2008). Thus, the quality is not to satisfy a number of criteria set by a library / institution, but aims to meet the quality criteria set by library user. The main factors affecting the quality of service are a service that is expected library user (expected service) and perception of the service (perceived service) (Parasuraman in Tjiptono, 2008). If the perceived service in accordance with the expected service, then the quality of the service in question will be considered good or positive. If the perceived service exceeds the expected service, then the quality of service perceived as an ideal quality. Instead perceived service worse than expected service, then the quality of service perceived as negative or bad. As the key to the meaning of this quality knows who the users are and what they want. Roger (1995: 157) defines quality as the suitability of the use of the means of goods or services in order to meet the needs of customers or users. Garvin and Davis in Nasution (2004: 41) states, that the quality of the environment is dynamic conditions that meet or exceed the expectations of customers or users.

Service is any activity that benefits can be given from one party to another that is essentially intangible and does not result in ownership of something (Kotler, 1985: 352). Definition of the service itself according Sugiarto (2002: 216) is the maximum effort given by service personnel from an industrial company to meet the expectations and needs of customers in order to reach satisfaction. Definition of Nasution (2004: 47), quality of service is the expected level of excellence and control over the level of excellence to meet customer desires. Meanwhile, according to Rangkuti (2003: 23), quality of service is to recognize the needs / interests of customers and end on customer perception. This means that the picture quality should refer to the views of customers and not on the service provider, because the customer who consumes and enjoy the services. Worthy customers determine quality of service was good or not. Rangkuti (2003: 109) using analysis Importance and Performance Matrix to measure the quality of service.

In terms of assessment of service quality, Parasuraman et al. (1985) dalan Hardiyansyah (2011: 92) defines the assessment of service quality as a global judgment or attitude that is associated with the advantage (superiority) of a service (services). In other words, the assessment of the quality of service is equal to the individual's attitude in general towards the performance of the library. Then added that the assessment of service quality is the level and direction of the difference between the perceptions and expectations of users. The difference between perception and expectations that underlie the emergence of the concept of gap (perception-expectation gap) and used as the basis of service quality scale, which is based on five dimensions of quality: (1) tangibility, including physical facilities, equipment, personnel and means of communication; (2) reliability, namely the company's ability to provide the promised service in a timely and satisfactory; (3) responsiveness, the ability of the staff to help customers and provide service with a response; (4) assurance, covering ability, courtesy and trustworthiness owned by the staff, free from danger, risk or doubt; (5) empathy, include ease of doing good communication and understand the needs of customers. 
Various definitions have been described above and can be deduced notion of quality of service that all forms of service delivery to the maximum provided the company with all the benefits in order to meet customer needs in order to meet customer expectations. The services sector that produces products in the form of service have distinctive characteristics, the use of management techniques quality standards would not be appropriate because of the distinctive nature. Some researchers and academics to develop several methods to locate, measure, and analyze the determinants of quality of service. Service quality need to be measured at least three reasons (Nashihudin, 2010) namely:

- The measurement results can be used to perform a comparison between before and after the occurrence of a change in an organization

- Measurement is needed to find out where problems related to quality

- Results of measurements are required to set service quality standards.

All of these benefits in turn contribute to the improvement of sustainable competitiveness for organizations seeking compliance with quality and customer-driven nature. Long-term period's institution or agency such as this will survive in the era of globalization.

Satisfaction library user / Users: Basically the concept of satisfaction library user still abstract. Many experts define the library user satisfaction. General understanding regarding library user satisfaction or dissatisfaction is the result of differences between the expectations library user with the performance perceived by the library user. Definition of user satisfaction were also presented by Tse and Wilson (in Nasution, 2004: 104) that the satisfaction or dissatisfaction of the user is the user's response to the evaluation or disconfirmation of the perceived discrepancy between prior expectations and actual performance product that is felt after usage. It means that users will be satisfied if the results are as expected and instead users will be dissatisfied if the results are not in line with expectations. In accordance with the opinion of Kuswadi (2004: 16) the satisfaction of users, namely the difference between user expectations and user's perception of what a given library. According to Amir (2005: 13) user satisfaction is the extent to which the benefits of a product perceived (perceived) according to what users expect. Then simply the satisfaction of users is a product or service that can meet or exceed the expectations of users, usually the user is satisfied (Gerson, 2002: 5).

Of the various opinions expressed by the experts could conclude the definition of user satisfaction is the response of the behavior exhibited by the user by comparing perceived performance or results to expectations. If the result is felt below expectations, then the user will be disappointed, less satisfied even dissatisfied, but otherwise if in line with expectations, users will be satisfied and when performance exceeds expectations, users will be very satisfied. From the diverse definitions of user satisfaction which has been researched and defined by marketing experts, it can be concluded that user satisfaction is a response in the form of user behavior evaluation after purchase of the goods or services he feels (product performance) compared with user expectations. User satisfaction is highly dependent on the perceptions and expectations of the users themselves. Factors that influence the perceptions and expectations of users when making a purchase of goods or services is the need and desire felt by the user at the time of making a purchase of goods or services, past experience when consuming goods or services and the experiences of friends who have been consumer goods or services and advertising.

\section{Methodology}

This is quantitative research. This method was chosen because research on the quality of library services requires the scale of measurement of indicators of service asked of respondents. Research on the quality of library services is a descriptive study. Descriptive research is used in research involving researchers in an environment that will be examined and these studies are usually intended to solve problems systematically based on factual data obtained. UPT research sites in the Cenderawasih University Library. The research variables consisted of independent variables physical evidence, reliability, responsiveness, assurance and variable empathy as well as the dependent variable is user satisfaction. The population in this study is the average number of library visitors per month throughout the year 2013, which amounted to 856 people. The sampling using Proportional Probability Sampling techniques with Stratified Random Sampling, which means 
sampling of members of the population at random and stratified in proportion to the total sample of 90 respondents.

\section{Results}

Multiple regression results indicate that the independent variable that is tangible, reliability, empathy and positive influence on the dependent variable customer satisfaction. While the variable responsiveness and assurance negatively affects library user satisfaction.

Table 1: Regression Analysis

\begin{tabular}{|c|c|c|c|c|c|c|}
\hline \multirow{2}{*}{\multicolumn{2}{|c|}{ Model }} & \multicolumn{2}{|c|}{$\begin{array}{l}\text { Unstandardized } \\
\text { Coefficients }\end{array}$} & \multirow{2}{*}{$\begin{array}{l}\text { Standardized } \\
\text { Coefficients } \\
\text { Beta }\end{array}$} & \multirow[t]{2}{*}{ t } & \multirow[t]{2}{*}{ Sig. } \\
\hline & & B & Std. Error & & & \\
\hline \multirow{6}{*}{1} & (Constant) & 15804 & 1,611 & & 9,812 & 0.000 \\
\hline & Tangible & 0.310 & 0.105 & 0.381 & 2,241 & 0.018 \\
\hline & Reliability & 0.334 & 0.107 & 0.457 & 3,166 & 0.007 \\
\hline & Responsiveness & 0.053 & 0.161 & 0.060 & 0.331 & 0.741 \\
\hline & Assurance & -0.005 & 0.128 & -0.007 & -0.039 & 0.969 \\
\hline & Empty & 0.350 & 0.106 & 0.464 & 3,298 & 0.001 \\
\hline
\end{tabular}

Dependent Variable: Satisfaction library user, $\mathrm{F}=2.623, \mathrm{p}=0.030, \mathrm{R}^{2}=13.5 \%$

The results Showed that the quality of service which consists of tangible, reliability, responsiveness, assurance, empathy, and together have a positive influence. Service quality has a significant effect on satisfaction of library users at the University Library of Cenderawasih. The variables that have a significant influence on satisfaction of library users are tangibles, reliability and empathy. Responsiveness and assurance does not have a significant influence on satisfaction in the Library Unit Uncen library users. The most dominant variable is empathy.

Discussion: Tangible significant effect on satisfaction library user. Physical evidence is physical Uncen Library Unit, such as the comfort of the room, book room arrangement, interior and exterior good, neatness and cleanliness of the room and the staff as well as the technology used. This physical evidence could affect the comfort and smoothness in providing service to each library user. Most respondents stated that the physical conditions at the Library Unit Uncen enough library user liking. The more support the physical conditions in Uncen Library Unit, then it will affect the satisfaction of library user. Reliability significantly influences library user satisfaction. Reliability is the ability to provide the promised service promptly, accurately and satisfactorily by the Library Unit Uncen, such as punctuality when promised, to be honest in the service and try to avoid mistakes. This means that the company provides appropriate services since the first moment. Reliability here is the extent to which the library staff can be responsive to understand and address the problems faced by the library user. The more reliable the results shown by the staff, the problems faced by the library user will be quickly resolved. The higher the level of reliability Uncen Library Unit, then it will affect library user satisfaction.

Responsiveness no significant effect on satisfaction library user in Uncen Library Unit. Responsiveness means that the response or the alertness of staff in helping library user and provide fast delivery of library services. The higher the responsiveness shown by the staff the problems faced by customers library will be quickly resolved. Different things happen in the Library Unit Uncen, that despite the more the higher or the lower the responsiveness of staff in providing services will not give satisfaction to the existing library user. Many library user which activity in searching for books or reference materials in the library Uncen feel less sensitive staff in providing services. This was felt library user responsiveness of staff would not be good if it is not accompanied by a sincere intention to work to serve give responsiveness. The higher or lower the responsiveness shown by the staff Uncen Library Unit, then it will not affect the library user satisfaction. Assurance has no effect on customer satisfaction in the Uncen Library Unit. Collateral is the knowledge, ability, courtesy, and trustworthiness owned by the library staff if not accompanied by a sense of good empathy by the staff and employees of the does not have implications for library user satisfaction. So despite 
the higher assurance shown by the staff Uncen Library Unit, then it will not affect the library user satisfaction. Empathy is the ease in relationships, good communication, personal attention, and understand the needs of customers by Uncen Library Unit staff, such as attention to library user, responsibility for security and comfort as well as the interests of the customers of the library. The higher the empathy shown by the staff Uncen Library Unit, it will affect customer satisfaction library.

\section{Conclusion}

Results of the study provide some conclusions. There is positive and significant correlation between the qualities of services to satisfaction library user in Uncen Library Unit. Individually of five variables that affect satisfaction Library Unit Uncen library user in Jayapura, the most dominant variable is a variable Empathy then variable tangible (physical evidence) and the last variable reliability. While variable Responsiveness and Assurance (guarantee) individually does not have a significant impact on satisfaction library user in Uncen Library Unit. Some aspects of library services should receive major attention. The ability and the number of employees who are still confined primarily educational backgrounds S1 and S2 Library Science only 2 people that affect the productivity of labor. The library's physical facilities such as tables, chairs, bookcases many are eaten by termites, there are only two computers that can be used for OPAC are supposed 10 computers, and even then still a Pentium computer. Collection of library materials, especially books and magazines not meet the needs of library user because most books published long while only magazine of course no one gift subscription. The type of service that is limited to the circulation service, no other services such as Internet services are not available.

Suggestion: Uncen Library Unit further enhances the satisfaction of the library user. The ability of employees need to be improved to include educational and training organized by the National Library, and further study Science Library and the addition of employees with educational background D3 / S1 Library Science. The physical facilities should be improved and supplemented, the availability of tables, chairs, cabinets and bookshelves, AC facilities for the comfort of the main room as well as the availability of computers better and meet the standards for libraries. The library collection of books, magazines and the latest reference collection should be increased every year. Very necessary network facilities internet connectivity.

\section{References}

Amir, M. T. (2005). Edisi Pertama. Dinamika pemasaran jelajahi dan rasakan. Jakarta: PT RajaGrafindo Persada

Garvin, D. A. (1988). Managing Quality: the strategic and Competitive Edge. New York: Free Press

Gerson, R. F. (2002). Mengukur kepuasan pelanggan. Jakarta:Penerbit PPM

Hardiyansyah. (2011). Kualitas pelayanan publik. Yogyakarta: Gava Media

Kotler, P. (1985). Prinsip-prinsip dasar pemasaran. Jakarta: Grafindo

Kuswadi. (2004). Cara mengukur kepuasan karyawan. Jakarta: PT Elex Media Komputindo

Nashihuddin, W. (2010). Serqual; Metode Tepat Meningkatkan Kualitas Layanan Perpustakaan. http://pustaka1987.wordpress.com/2010/09/03/servqual-metode-tepat-meningkatkan-kualitaslayanan-perpustakaan/ [diakses 15-07-2013]

Nasution, M. N. (2004). Manajemen jasa terpadu. Bogor: Ghalia Indonesia

Parasuraman, A., Zeithaml, V. A. \& Berry, L. L. (1985). A conceptual model of service quality \& its implications for future research. Journalof marketing, 49(2).

Rangkuti, F. (2003). Teknik Mengukur dan Strategi meningkatkan kepuasan pelanggan. Jakarta : Gramedia Pustaka Utama

Roger, G. S. (1995). Implication for marketing strategy. Dallas: BPS

Sugiarto, E. (2002). Psikologi pelayanan dalam industri jasa. Jakarta: Gramedia Pustaka Utama

Tjiptono, F. (2008). Service Management: Mewujudkan Layanan Prima. Yogyakarta : Andi Offset 